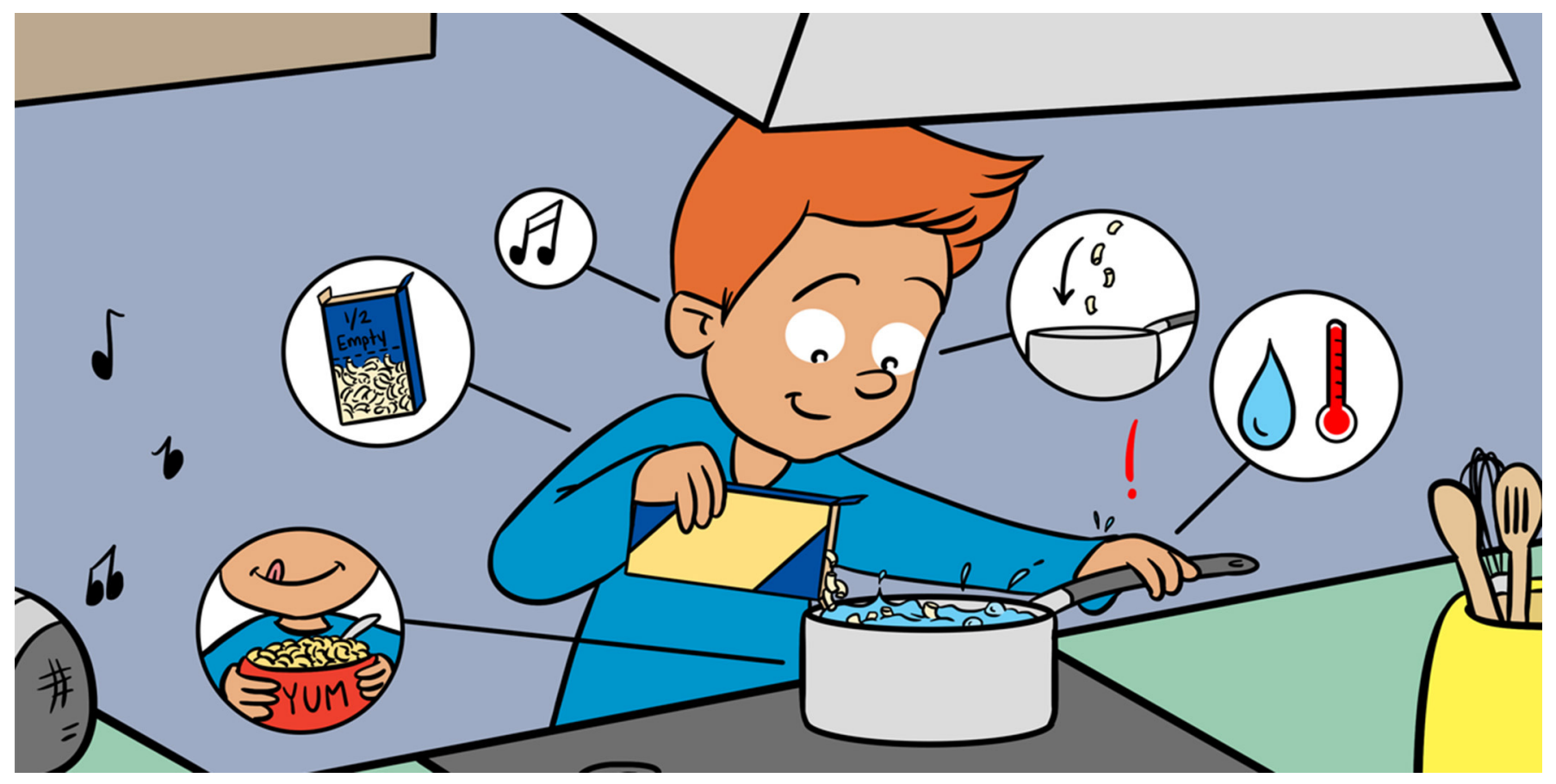

\title{
WHAT IS OUR MOST IMPORTANT SENSE?
}

\section{Fabian Hutmacher ${ }^{1,2 *}$}

${ }^{1}$ Department of Psychology, University of Regensburg, Regensburg, Germany

${ }^{2}$ Human-Computer-Media Institute, University of Würzburg, Würzburg, Germany

\section{YOUNG REVIEWERS:}

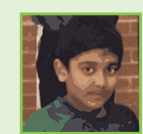

SARUJAN

AGE: 14

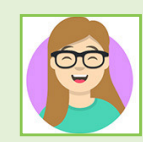

JULIA

AGE: 14

WILL

AGE: 15
For most people, vision is their most important sense. Indeed, vision is crucial in many situations of our daily lives-like reading this article. Additionally, a large part of the human brain is dedicated to processing visual information, while information from the other senses is processed in much smaller brain regions. However, we should not forget about the importance of our other senses too quickly. Each sense provides us with unique information about ourselves and the world. In other words, each sense captures a different aspect of reality. If we understand this, we can start to appreciate the richness and diversity of our sensory abilities in a new way. We can be grateful that we have all of our senses and that they give us such a diverse access to the world.

\section{INTRODUCTION}

Humans have five senses: vision, hearing, touch, smell, and taste. All of these senses are important in our daily lives. It would be a pity if we were unable to taste and smell the birthday cake that our families 
Figure 1

In an online survey, participants were asked which sense they are most afraid to lose (for details, see [1]). About $75 \%$ of participants said that they are most scared of losing their sense of vision. About $15 \%$ of participants claimed to be most scared of losing their sense of hearing, and $10 \%$ their sense of touch. Only one participant claimed to be most scared of losing the sense of taste, and no one claimed to be most scared of losing the sense of smell. This survey was conducted in a Western country (Germany), which may influence the results, as explained in the text.

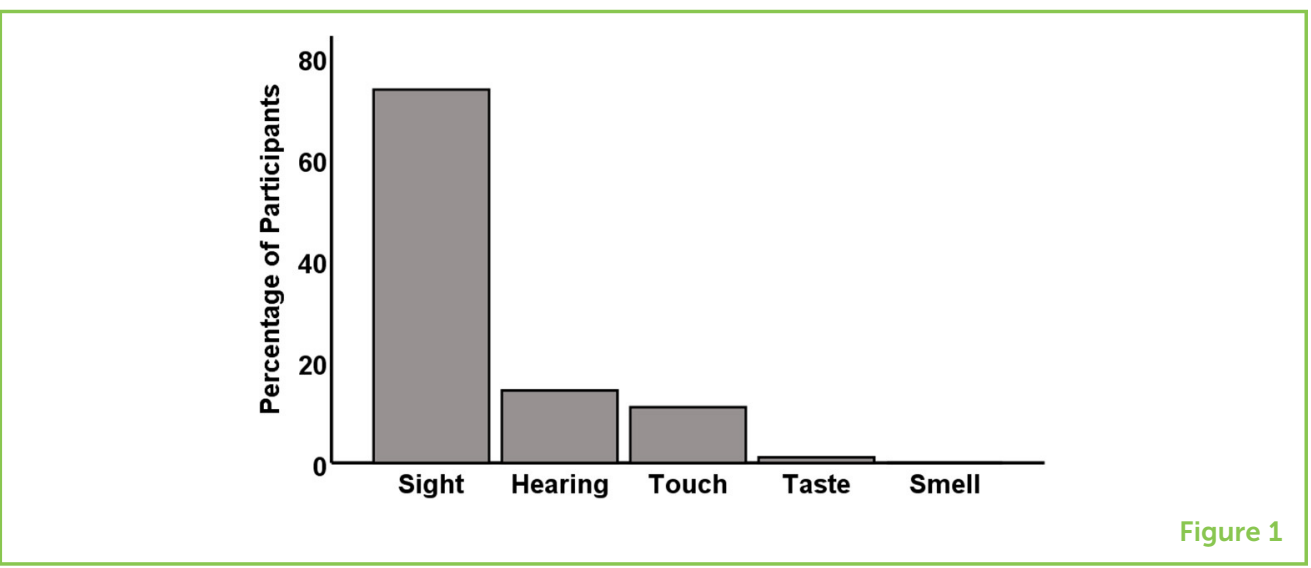

have prepared for us, to hear conversations or listen to music, to see the world around us, or to feel the hug of a friend. However, what do you think-which is your most important sense? In other words, which sense would it scare you the most to lose? I asked this question in an online survey. Ninety-one people responded, out of which 67 claimed that they are most scared of losing their sense of vision (Figure 1). That is about three quarters of respondents, an overwhelming majority. Why is that?

\section{THE IMPORTANCE OF ALL FIVE SENSES}

It is easy to see why we might feel that losing the sense of vision would be worse than losing any other sense, primarily because of the importance of vision in our daily lives. Most hobbies that people enjoy would be impossible without the ability to see, such as reading books, watching movies, playing computer games, riding a bike, or playing football. The same applies to many of our daily routines. Imagine, for instance, how difficult it would be to pick your favorite sweets from the shelves in the supermarket-or even to find the correct shelf. Also think about how much learning at school depends on your ability to see what your teacher is writing on the board. So, it is easy to understand why people are afraid of losing their sense of vision-it would change their lives profoundly. However, it is important to keep in mind that our societies offer a wide range of support to blind people, so that they can remain active members of their communities. Losing the sense of vision does not normally endanger a person's survival or even that person's ability to function in society. Interestingly, it has been shown that hearing and touch may become more sensitive in blind individuals [2].

For comparison, imagine losing your sense of touch. You would not feel anything when hugging your loved ones or when caressing their faces. You could not tell whether you were comfortably seated. You would not notice when stepping barefoot on a piece of broken glass (unless you saw the blood coming from your wound). Do you find this 
hard to imagine? I do. We know very well how it feels when our cheek is numb after we have been at the dentist. Experiencing such a numbness all over the body must be scary and disturbing, as we can learn from the case of Ian Waterman [3]. Ian Waterman was 19 years old when he lost his sense of touch, probably as the result of an unusual reaction to a viral infection. Technically, he was still able to move his muscles, but he was unable to do so in a controlled manner. He had absolutely no feeling for the positions of his limbs. It took him 2 months to learn how to sit and another year and a half to stand up. One and a half years of daily exercise to be able to stand up! Just think about how much mental effort that must have cost him.

The case of Ian Waterman illustrates how lost we would be without the sense of touch and how much we rely on it in our daily lives, most of the time without noticing it. Should we conclude from this that touch, and not vision, is our most important sense? I do not think so-vision is important! Rather, I want to draw your attention to the fact that our various senses have different functions. They capture different aspects of the world around us. What does that mean? To walk, we need to know the position of our body parts and we need to know whether we have a firm footing on the ground. This is information the sense of touch provides us with very easily. When starting to walk around, however, it is the sense of vision that leads the way. You look for the things that you want to buy in the supermarket; then you start walking toward them until you see that they are within your reach. In short, touch is fundamental for feeling our own bodies and the borders between our bodies and the world, while vision is fundamental for navigating within the world. Similar things could be said about the other senses. In other words, each sense is of crucial importance for us as human beings, but for different reasons. If we understand this and start to appreciate the richness and diversity of our sensory abilities, ranking any of the senses as "most important" becomes less relevant.

\section{SENSES AND THE BRAIN}

There is a second argument that is often used to explain why vision is so important for us as human beings. It is commonly assumed that a large part of the human brain is dedicated to processing visual information, while information from the other senses is processed in much smaller brain regions. However, this argument has been questioned in recent years [4]. For instance, some brain regions that were previously believed to process only visual information have been found to process information from other senses too. Moreover, the brain does not process information from the senses separately, but combines them into one perception. That makes sense-to know whether you like the birthday cake that your family has prepared for you, you need to know how it smells and tastes and looks, and maybe even how it feels in your mouth. 
We could also ask an even more fundamental question: why should the size of the brain region specialized for processing information from a certain sense be the factor that determines the importance of that sense? We could also look at other factors that determine importance. For instance, the skin, which contains the receptors for touch, is the largest sensory organ of the human body, accounting for more than a tenth of the body's weight! Again, this is not meant to dispute the importance of vision, but to show that we should not forget about our other senses too quickly.

\section{COMPARING DIFFERENT TIMES AND CULTURES}

The importance of all the senses also becomes obvious when we look at cultures different from our own. For instance, a recent study investigated 20 different languages to find out how many details they contain for describing impressions with the five senses [5]. For instance, one language may have a very limited number of words to describe taste, such as "bitter" or "sweet." Another language may have a more detailed vocabulary, including a word for "sweet-at-first-but-slightly-bitter-after-chewing-it-for-a-while." In some languages, like English, the vocabulary to describe visual impressions is more detailed than the vocabulary to describe impressions from the other senses. However, languages like Turkish and Farsi are particularly good at expressing differences in taste, and languages such as Dogul Dom spoken in Mali are particularly good at expressing differences in touch. As it seems, not all cultures are as highly focused on vision as our modern, Western societies.

Our high level of focus on vision is also seen clearly when we compare our present societies to those of the past. Our current world is more visual than ever before [6]. Beginning with the invention of movies, cinema, and television, but even more so after the invention of smartphones and computers, visual technologies have become an important part of our daily lives. Basically, we look at screens all day long-to check messages on our smartphones, to post new pictures on social media, to read the news, to watch the latest episodes of our favorite shows, and so on. So, you can see that our impression that vision is our most important sense is probably reinforced by the fact that we live in societies that are dominated by visual input.

\section{CONCLUSION: THE DIVERSITY OF THE SENSES}

Humans have five senses-and that is fantastic! Each sense provides us with unique information about ourselves and the world around us. When we want to pick our favorite sweets from the shelves in the supermarket, we need vision to spot them amongst all the other sweets. When we reach for them, we need our sense of touch to tell us whether we are holding the package firmly enough to put it into the 
shopping cart. When we eat those sweets, we are interested in their smell and taste. And when we want to tell our friends how tasty the sweets are, our friends will need the ability to hear. So, although most of us believe that vision is the most important sense, we should be grateful that we have four more senses-and that, together, they give us such a diverse access to the world.

\section{ORIGINAL SOURCE ARTICLE}

Hutmacher, F. 2019. Why is there so much more research on vision than on any other sensory modality? Front. Psychol. 10:2246. doi: 10.3 389/fpsyg.2019.02246

\section{REFERENCES}

1. Hutmacher, F. 2019. Why is there so much more research on vision than on any other sensory modality? Front. Psychol. 10:2246. doi: 10.3389/fpsyg.2019.02246

2. Cattaneo, Z., and Vecchi, T. 2011. Blind Vision: The Neuroscience of Visual Impairment. Cambridge, MA: MIT Press.

3. Cole, J. 1995. Pride and a Daily Marathon. Cambridge, MA: MIT Press.

4. Ghazanfar, A. A., and Schroeder, C. E. 2006. Is neocortex essentially multisensory? Trends Cogn. Sci. 10:278-85. doi: 10.1016/j.tics.2006.04.008

5. Majid, A., Roberts, S. G., Cilissen, L., Emmorey, K., Nicodemus, B., O'Grady, L., et al. 2018. Differential coding of perception in the world's languages. Proc. Natl. Acad. Sci. 115:11369-76. doi: 10.1073/pnas.1720419115

6. Mirzoeff, N. 1999. An Introduction to Visual Culture. London; New York, NY: Routledge.

SUBMITTED: 01 April 2020; ACCEPTED: 02 July 2021;

PUBLISHED ONLINE: 28 July 2021.

EDITED BY: Caroline A. Niziolek, University of Wisconsin-Madison, United States

CITATION: Hutmacher F (2021) What Is Our Most Important Sense? Front. Young Minds 9:548120. doi: 10.3389/frym.2021.548120

CONFLICT OF INTEREST: The author declares that the research was conducted in the absence of any commercial or financial relationships that could be construed as a potential conflict of interest.

COPYRIGHT @ 2021 Hutmacher. This is an open-access article distributed under the terms of the Creative Commons Attribution License (CC BY). The use, distribution or reproduction in other forums is permitted, provided the original author(s) and the copyright owner(s) are credited and that the original publication in this journal is cited, in accordance with accepted academic practice. No use, distribution or reproduction is permitted which does not comply with these terms. 

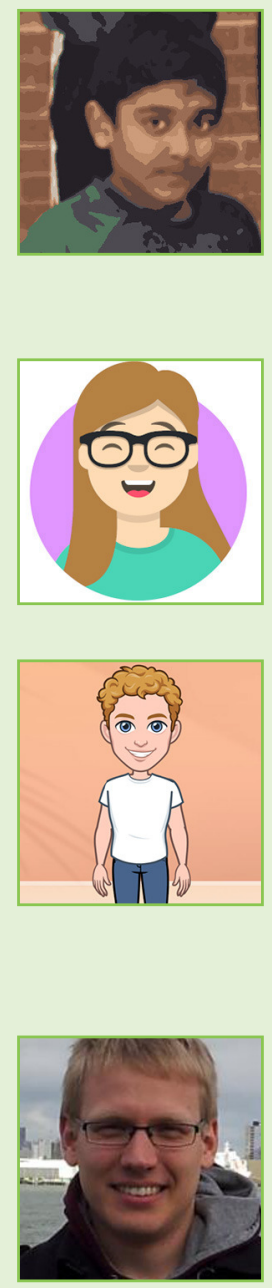

\section{YOUNG REVIEWERS}

\section{SARUJAN, AGE: 14}

I am 14 and my name is Sarujan. I like to play sports in my free time like basketball and soccer. However, exploring parks and trails is the most exciting part for me since I can usually find all sorts of cool insects around my neighborhood. I am learning how to play the trombone and having a lot of fun doing so. I hope to someday become a scientist and continue learning about the different animals around the world.

\section{JULIA, AGE: 14}

My name is Julia, I am 14, and I am in 8th grade. I like to swim and I play the saxophone. I enjoy reading, and one of my favorite series is the Keeper of the Lost Cities series by Shannon Messenger. One of my hobbies is baking, and I love pie.

\section{WILL, AGE: 15}

I love soccer-playing it, watching it, analyzing it. I also enjoy playing the flute as well as reading Manga and watching Anime. I am in 9th grade in a public independent study school and currently hope to be a Materials Scientist 1 day.

\section{AUTHOR}

\section{FABIAN HUTMACHER}

Fabian Hutmacher is a psychologist working at the University of Würzburg, Germany. He spends most of his time at work thinking about human perception and memory. Is not it fascinating that we can effortlessly remember details of things that we have seen years or even decades ago-while at the same time we struggle to recall where we left our keys? Is not it fascinating how much the memories for the same event differ between people? And is not it fascinating how diverse the experiences are that we create with our senses? *fabian.hutmacher@uni-wuerzburg.de 